\title{
A New Year Toast ... to the cardioprotective effects of alcohol
}

Why is the fact that alcohol has a significant protective effect against ischaemic heart disease regarded as dangerous information to be kept from a naive public? It is certainly not because the evidence for cardioprotection is weak.

The fact that alcohol consumption reduces both cardiovascular morbidity and mortality has been established by dozens of trials - with hundreds of thousands of subjects and millions of cumulative subject-years of follow up. Widely disparate populations have been studied: wine drinkers, ${ }^{1}$ healthy Americans, ${ }^{2}$ Puerto Ricans, ${ }^{3}$ British civil servants, ${ }^{4}$ American nurses, ${ }^{5}$ Japanese physicians, ${ }^{6}$ the Japanese in Hawaii, ${ }^{7}$ New Zealanders, ${ }^{89}$ Australians, ${ }^{10}$ Trinidadians, ${ }^{11}$ Yugoslavians, ${ }^{12}$ Danes, ${ }^{13}$ Welshmen, ${ }^{14}$ Finns, and various other American and British groups, including doctors. ${ }^{15-26}$ There were 584911 subjects with 5019644 subject years follow up in these 25 studies alone. Many different trial designs have been used: population observation, ${ }^{1}$ prospective cohort studies, ${ }^{2-7} 10-232526$ and case control studies. ${ }^{89}$ Follow up in these studies has lasted up to 23 years. ${ }^{2}$ All have shown that, compared with abstinence, moderate drinking protects against ischaemic heart disease. This protective effect, which is almost certainly causal, is not small-with reductions of $20 \%-80 \%$ in cardiovascular mortality (mean about $50 \%$ ). The protective effect is seen both in those at very low risk (Japanese physicians ${ }^{6}$ ) and in those at high risk (Finns ${ }^{15}$ ). The effects have often been described as U shaped, but in fact most studies 2 4-13 15 16 19-22 showed an inverse linear relation between alcohol intake and ischaemic heart disease, with protection increasing up to very high alcohol intakes. However, the curve for total mortality is usually $U$ shaped with excess mortality among regular drinkers (compared with teetotallers) occurring only at fairly high intakes of alcohol ( $>4$ drinks a day to $>6$ drinks a day).

Though evidence of a $U$ shaped relation has been accepted by the temperance lobby ${ }^{24}{ }^{25}$ they claim that the excess morbidity and mortality of non-drinkers is due to contamination of this group by ex-drinkers who gave up alcohol because of ill health-the sick quitters. This argument is clearly refuted by the studies that distinguished between lifetime abstainers and ex-drinkers: mortality in both groups was higher than in current drinkers 678101113162126 . In many ways the argument is specious. If alcohol is good for you, giving it up is likely to remove that protection over time. A New Zealand study suggests that the protective effects may be lost in the first 24 hours of abstinence, ${ }^{9}$ and some have suggested the excess of sudden deaths in binge drinkers occurs during withdrawal. A second explanation proposed for the $U$ shaped relation is that lifetime teetotallers have a greater burden of ill health on entry to the studies. Studies with data on health on entry again do not support this theory and the same protective effects of alcohol are seen when those who are ill are excluded. ${ }^{411} 192023$ Furthermore if abstainers were sick at entry, excess mortality should occur at the beginning of the study and gradually disappear with time. Studies with long-term follow up (up to 23 years) show no change over time in the level of protection afforded by alcohol. ${ }^{2} 1023$

\section{What about the excess of deaths caused by drinking?}

A widely quoted figure, that alcohol causes 28000 deaths a year in England and Wales, comes from a paper by Anderson. ${ }^{27}$ The logic in this paper was questionable. Moderate drinkers, at the bottom of the U shaped curve, rather that non-drinkers were used as the baseline reference group and then the figures from the worst study were extrapolated. The excess mortality was due both to excessive drinking and to abstinence: had the entire population stopped drinking the data suggest that deaths from coronary disease would have increased by $40 \%$. There were 167688 deaths caused by ischaemic heart disease in the United Kingdom in 1992 (Compendium of Health Statistics, 1992). Thus effective prohibition could increase by 67075 deaths caused by ischaemic heart disease in England and Wales each year. This excess mortality may begin to be seen after only 24 hours abstinence. ${ }^{9}$ An editorial in $\mathcal{F} A M A$ suggests that total abstinence in the United States would cause between 11556 and 135884 excess deaths per year. ${ }^{28}$ In most studies mortality is similar in total abstainers and heavy drinkers-so total abstinence by the small group of heavy drinkers would make little overall difference.

\section{Why is alcohol protective overall if it increases the} risk of many diseases?

Alcohol increases the risk only if taken in excess, and the diseases that alcohol is strongly associated with are much rarer than ischaemic heart disease. There is an excess mortality from sudden, presumed cardiac, death in heavy drinkers ( $>6$ drinks a day), but again the curve is $U$ shaped, with moderate drinkers having a lower total mortality than abstainers. ${ }^{29}$ What about cirrhosis? There is a relation between alcohol and liver disease, but cirrhosis is rare even in countries with high alcohol intake. It contributes to the excess total mortality in heavy drinkers $\left(>6\right.$ drinks a day in the Kaiser Permananente study ${ }^{16}$ ), but no excess of cirrhosis is seen with moderate alcohol intake. During the 18 year follow up in the Albany study there were 15 deaths from cirrhosis (seven in light drinkers or non-drinkers) and 173 deaths from coronary heart disease out of a total of 378 deaths. ${ }^{17}$

Alcohol seems to have a protective effect against ischaemic stroke but is associated with a higher rate of haemorrhagic stroke. ${ }^{5} 16$ Again, because haemorrhagic stroke is rarer, the total effect of moderate alcohol intake is protective against strokes. ${ }^{5}$

\section{What sorts of coronary events and deaths does alcohol help to prevent?}

Any alcoholic drink (raki, sake, beer, or wine) seems to 
be protective. ${ }^{12} 3031$ There is little evidence to suggest one is better than the other, although red wine may be the best. ${ }^{23031}$ It is scientifically sound to search for the nonalcoholic ingredient that is responsible for the protective effect but at present it is best to take the medicine as it comes. The habit of drinking wine with meals may well account for the French paradox-very low rates of coronary heart disease despite high dairy fat intakes, high serum cholesterols, and prevalent smoking. ${ }^{30}$

How does alcohol help? Moderate alcohol intake does not seem to reduce the amount of atherosclerosis in necropsy studies. ${ }^{32}$ Alcohol increases HDL concentrations but not enough to explain all its protective effect. ${ }^{20}$ It may interact with insulin resistance..$^{13}$ Phenolic substances in red wine may inhibit the oxidation of low density lipoproteins. ${ }^{31}$ There may also be an effect on platelets: they were less likely to aggregate in wine drinking French farmers than in their more abstemious Scots confrères. ${ }^{33}$ In another study in Scots, alcohol intake was negatively associated with fibrinogen concentrations. ${ }^{34}$ Further evidence that alcohol reduces the risk of thrombosis came from a report that moderate alcohol intake was associated with an increased concentration of endogenous tissue-type plasminogen activator. ${ }^{35}$ Alcohol reduced the release of catecholamine in response to stress. ${ }^{37}$

\section{Why then is this message not being given to the public?}

The message is reaching the public through the mass media but not the medical profession. Part of the reason that this information is suppressed lies in North America, where the temperance mentality holds sway. There is no doubt that excessive alcohol intake is the cause of many social ills including alcoholism. But should the undoubted ill effects of alcoholism and drunkenness be extrapolated to the point where all alcohol consumption is regarded as bad, where the road to alcoholism is deemed to be paved with moderate drinkers, and where all public health efforts are aimed at reducing alcohol intake. The temperance mentality also seems to be a factor in the United Kingdom. Some years ago the BMA forced underground its wine society, the Charles Hastings Wine Society; and, as the title of its report shows, the Royal College of Physicians regards alcohol as a great and growing evil. ${ }^{36}$ Distaste for the message that a moderate alcohol intake is good for you smacks of the Victorian ethic that says anything enjoyable cannot be good for you.

\section{What should we tell our patients with ischaemic heart disease?}

We have a duty to tell our patients and the wider public what lifestyle changes may be beneficial to them. The benefits of a change to a regular moderate intake of alcohol are equivalent to giving up smoking and are far greater than regular exercise or diet. The collected evidence (more than five million subject-years follow up) shows that moderate drinking is of more benefit than perhaps any other intervention in cardiology. Our advice should be "consume one or two drinks a day, preferably with meals and perhaps red wine". Patients already drinking at this level should be encouraged to continue, and lifetime teetotallers should be informed of the hazards of their continued abstinence. The hazards of heavy drinking should be highlighted and if necessary patients should be encouraged to cut their consumption. Similar, more carefully codified, guidelines appeared in
$\mathcal{F} A M A .{ }^{28}$ The timing and choice of beverage is not vitala little of what you fancy does do you good.

Queen Elizabeth Medical Centre,

Edgbaston, Birmingham B15 2TH

1 St Leger AS, Cochrane AL, Moore F. Factors associated with cardiac mortality in developed countries with particular reference to the consumption of wine. Lancet 1979;i:1017-20.

2 Friedman LA, Kimball AW. Coronary heart disease mortality and alcohol consumption in Framingham. Am $\mathcal{F}$ Epidemiol 1986;124:481-9.

3 Kittner SJ, Garcia-Palmieri MR, Costas R, et al. Alcohol and coronary artery disease in Puerto Rico. Am f Epidemiol 1983;117:538-50.

4 Marmot MG, Rose G, Shipley MJ. Alcohol Mortality: a U shaped curve. Lancet 1981;i:580-3.

5 Stampfer MJ, Colditz GA, Willett WC, et al. A prospective study of moderate alcohol consumption and the risk of coronary disease and stroke in women. $\mathrm{Engl}$ F Med 1988.319:267-73.

6 Kono S, Ikeda M, Tokudome S, et al. Alcohol and mortality: A cohort study of male Japanese physicians. Int $¥$ Epidemiol 1986;15:527-32.

7 Yano K, Rhoads GG, Kagan A. Coffee, alcohol and risk of coronary heart disease among Japanese men living in Hawaii. $N$ Engl f Med 1977;297: 405-9.

8 Jackson R, Scragg R, Beaglehole R. Alcohol consumption and risk of coronary heart disease. $B M \mathcal{F}$ 1991;303:211-6.

9 Jackson R, Scragg R, Beaglehole R. Does recent alcohol consumption reduce the risk of acute myocardial infarction and coronary death in regular drinkers. Am $\mathcal{f}$ Epidemiol 1992;136:819-24.

10 Cullen KJ, Knuiman MW, Ward NJ. Alcohol and mortality in Busselton, Western Australia. Am $\mathcal{F}$ Epidemial 1993;137:242-8.

11 Miller GJ, Beckles GLA, Maude GH, Carson DC. Alcohol consumption: Protection against coronary heart disease and risks to health. Int $f$ Epidemiol 1990:19:923-30.

12 Kozararevic D, Vojvodic N, Dawber $\mathrm{T}$, et al. Frequency of alcohol consumption and morbidity and mortality: The Yugoslavian cardiovascular disease study. Lancet 1980;i:613-6.

13 Hein HO, Sorenson H, Suadicani $\mathrm{P}$, et al. Alcohol consumption, Lewis phenotypes, and the risk of ischaemic heart disease. Lancet 1993;341: phenoty.

14 Fehily AM, Yarnell JW, Sweetnam PM, Elwood PC. Diet and incident ischaemic heart disease: the Caerphilly study. Br $\mathcal{F}$ Nutr 1993;69: 303-14.

15 Salonene JT, Puska P, Nissinen A. Intake of spirits and beer and risk of myocardial infarction of health-a longitudinal study in Eastern Finland. F Chron Dis 1983;36:533-43.

16 Klatsky AL, Armstrong MA, Friedman GD. Relations of alcoholic beverage use to subsequent coronary artery disease hospitalisation. $A m \mathcal{F}$ Cardiol 1986;58:710-14.

17 Gordon T, Doyle JT. Drinking and mortality. The Albany study. Am $\mathcal{J}$ Epidemiol 1987;125:263-70.

18 Camacho TC, Kaplan GA, Cohen RD. Alcohol consumption and mortality in Alameda county. $f$ Chron Dis 1987;40:229-36.

19 Rimm EB, Giovannucci EL, Willett WC, et al. Prospective study of alcohol consumption and risk of coronary disease in men. Lancet 1991;338:464-8.

20 Suh I, Shaten BJ, Cutler JA, Kuller LH. Alcohol use and mortality from coronary heart disease: the role of high-density lipoprotein cholesterol. The multiple risk factor intervention trial research group. Ann Intern Med 1992;116:881-7.

21 de Labry LO, Glynn RJ, Levenson MR, Hermos JA, et al. Alcohol consumption and mortality in an American ageing population: recovering sumption and mortality in an American ageing population: recovering Alcohol 1992;53:25-32.

22 Linn S, Carroll M, Johnson C, et al. High density lipoprotein cholesterol and alcohol consumption in US black and white adults: data from and alcohol consumption in US black and white

23 Boffetta P, Garginkel L. Alcohol drinking and mortality among men enrolled in an American cancer society prospective study. Epidemiology 1990;1:342-8.

24 Shaper AG. Alcohol and mortality: a review of prospective studies. $\mathrm{Br} \mathcal{F}$ Addiction 1990;85:837-47.

25 Shaper AG, Wannamethee G, Walker M. Alcohol and mortality in British men: explaining the U shaped curve. Lancet 1988;ii:1267-73.

26 Dole $R$, Peto $R$, Hall E, et al. Mortality in relation to consumption of alcohol: 13 years' observations on male British doctors. $B r$ Med F 1994; 309:911-8.

27 Anderson P. Excess mortality associated with alcohol consumption. BMF 1988;297:824-6.

28 Pearson TA. What to advise patients about drinking alcohol. The clinician's conundrum. $7 A M A$ 1994;272:967-8.

29 Wannamethee G, Shaper AG. Alcohol and sudden death. Br Heart $\mathcal{F}$ 1992;68:443-8.

30 Renaud S, de Lorgeril $M$. Wine, alcohol, platelets and the French paradox for coronary heart disease. Lancet 1992;339:1523-6.

31 Frankel EN, Kanner J, German JB, et al. Inhibition of oxidation of human low-density lipoprotein by phenolic substances in red wine. Lancet 1993:341:454-7.

32 Moore RD, Pearson TA. Moderate alcohol consumption and coronary artery disease. A review. Medicine 1986;65:242-67.

33 Renaud S, Morazain R, Godsey, et al. Nutrients, platelet function and composition in nine groups of French and British farmers. Atherosclerosis 1986;60:37-48.

34 Lee AJ, Smith WC, Lowe GD, et al. Plasma fibrinogen and coronary risk factors. F Clin Epidemiol 1990;43:913-9.

35 Ridker PM, Vaughan DE, Stampfer MJ, et al. Association of moderate alcohol consumption and plasma concentration of endogenous tissuetype plasminogen activator. $\mathscr{f} A M A$ 1994;272:929-33.

36 Royal College of Physicians. A great and growing evil. London: Tavistock, 1987.

37 Pohorecky LA. Interaction of alcohol and stress at the cardiovascular level. Alcohol 1990;7:537-46. 